\section{Rediscovering the unconscious mind}

\author{
John Launer
}

Most people nowadays subscribe to the idea that our minds have both a conscious part and an unconscious one. The idea is usually attributed to Sigmund Freud but was first proposed by the German philosopher Arthur Schopenhauer, who argued that our actions were largely determined by passions of which we were unaware. Freud later popularised the notion with his book 'The Interpretation of Dreams.' He suggested that our dreams revealed, in a coded form, the hidden desires that actually govern our behaviour. He went on to describe a system of unconscious drives, which he believed appeared in infancy but were then forgotten or 'repressed' because they were incompatible with the conduct of civilised life. He believed emotional conflict arose from a failure to repress such drives in a satisfactory way, and devised his 'talking cure', psychoanalysis, to treat this.

Freud's system of thought quickly became influential in the western world in the first half of the twentieth century. It then declined in popularity, at least in its original form. The lack of evidence for some of its tenets, including the alleged tendency of adults to forget traumatic events from their childhood, lessened its credibility. It also seemed to depend on the subjective claims of its practitioners, who often disagreed among themselves about how the unconscious mind actually worked, and tended to dismiss dissent as evidence of mental disturbance in their opponents.

In spite of this, there is still general acceptance of some of the ideas that emerged from Freud and his followers, and good evidence to support these. This includes the idea that good parenting and a secure childhood are more likely to lead to a happy and productive life than abuse and a troubled family background. In addition, different forms of the 'talking cure', all originally derived from Freud and psychoanalysis, do seem to relieve certain kinds of emotional problems, although this may sometimes depend more on a compassionate relationship with the therapist than on any set of ideas about the nature of the unconscious mind.

Correspondence to Dr John Launer, Faculty Development, Health Education North West London, Stewart House, 32 Russell Square, London WC1B 5DN, UK: john.launer@londondeanery.nhs.uk

\section{SEXUAL DRIVE}

If we go back to Schopenhauer's original idea about the unconscious mind, it turns out to be rather surprising, and in some ways prescient. Here is what he actually said: 'Man is concrete sexual drive; for his origin is an act of copulation, and his desire of desires is an act of copulation, and this impulse alone perpetuates and holds together the whole of his phenomenal existence. ${ }^{1}$ This is not just a claim that human beings seek to have sexual intercourse. $\mathrm{He}$ was arguing that we are all the product of reproduction, and the vehicles by which the process of reproduction carries on. Hence our minds are organised, as they must be, around the perpetuation of that principle. His argument thus anticipates the notion of the 'selfish gene', putting the drive for genetic continuity before all others. It also bears a remarkable resemblance to the area of thinking known as evolutionary psychology.

Modern evolutionary psychologists argue that the mind is essentially a calculating apparatus for pursuing our own reproductive interests, either in the short or longer term, and in both direct and indirect ways. For a relatively short proportion of our lives, this literally entails seeking sexual intercourse and conception. For the vast majority of our lives, it involves activities that contribute to our own continuity and that of our kin in other ways. These include child-rearing, or investing in our future and community through work, recreation and other pursuits. The case is put forward nicely by the biologist Bobbi Low:

'All living organisms have evolved to seek and use resources to enhance their reproductive success. They strive for matings, invest in children or help other genetic relatives, and build genetically profitable relationships. In biology, this is not a controversial proposition, and it follows that organisms will act as though they are able to calculate costs and benefits. $^{2}$

\section{THE EVOLUTIONARY UNCONSCIOUS}

Evolutionary psychologists are now revisiting the idea of the unconscious mind, although not in exactly the way Freud applied it. For example, the leading evolutionary theorist Robert Trivers has proposed that self-deception is a vital component in the struggle for survival and reproduction, and possibly the most crucial one. If we understood how relentlessly we pursue our own interests, he argues, we would do so far less subtly. We would also give away clues to others, making it easier for them to decipher our behaviour, and hence to thwart us. ${ }^{3}$

Another interesting take on evolved behaviour comes from the study of mental disorders, where a number of psychologists and psychiatrists are suggesting that apparently dysfunctional problems like depression may be ways of responses to losing reproductive resources, giving unconscious signals of a withdrawal from competition that may actually be selfprotective. $^{4,5}$

In many respects, the different ways that psychoanalysts and evolutionists regard the unconscious are still poles apart. Most therapists and counsellors regard evolutionary psychology as hopelessly deterministic. Many biological scientists regard Freud's theories as self-referential, and unrelated to any recognisable scientific principles. By and large, they have shown little interest in trying to apply their ideas to the talking therapies. However, this state of affairs is now changing, and there are signs of a rapprochement from both sides. ${ }^{5}$ If I was to put my money on one intellectual development in the twenty-first century that will change our approach to the mind more than any other, I would place it on the likelihood that people with radically different views of the human mind - the psychoanalytic and evolutionary ones - will find common ground in their understanding of the unconscious mind.

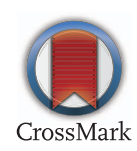

To cite Launer J. Postgrad Med J 2014;90:182.

Postgrad Med J 2014;90:182.

doi:10.1136/postgradmedj-2014-132609

\section{REFERENCES}

1 Schopenhauer A. The World as Will, Representation vol. 2. (1844) Trans. Payne E.F. J. New York NY: Dover Publications 1966.

2 Low B., Why Sex Matters: A Darwinian Look at Human Behavior. Princeton NJ, Princeton University Press, 2001.

3 Trivers R. Deceit and Self-Deception: Fooling Yourself the Better to Fool Others. London: Allen Lane 2011.

4 Gilbert $P$. The evolution of social attractivenessits role in shame humiliation, guilt, therapy. Br J Med Psychol 1994; 70:113-147.

5 Nesse R. An evolutionary framework for understanding grief. In: Carr D, Nesse RM, Wortman CB, eds. Spousal Bereavement in Late Life,. New York NY: Springer 2005: 195-226.

6 Gilbert P Bailey K, eds. Genes on the Couch: Explorations in Evolutionary Psychotherapy. Hove, UK: Brunner-Routledge 2000. 